\title{
KAJIAN PERILAKU MODEL MATEMATIKA PENULARAN PENYAKIT TUBERCULOSIS
}

\author{
FAIZAL HAFIZ FADILAH, ZULAKMAL \\ Program Studi Matematika, \\ Fakultas Matematika dan Ilmu Pengetahuan Alam, Universitas Andalas, \\ Kampus UNAND Limau Manis Padang, Indonesia, \\ email : faizalhafizfadilah@gmail.com
}

\begin{abstract}
Abstrak. Penyakit Tuberculosis merupakan salah satu penyakit menular yang disebabkan oleh bakteri Mycrobacterium Tuberculosis. Bakteri ini menyebar melalui udara dan biasanya menyerang paru-paru. Pada saat ini, Tuberculosis menjadi penyakit yang serius dan mematikan bagi manusia sehingga masyarakat sebaiknya memiliki informasi untuk mengenali dan mencegah penyakit ini. Dari hasil analisis terhadap model diperoleh titik kesetimbangan bebas penyakit $E_{0}$ dan titik kesetimbangan endemik $E_{1}$. Selanjutnya dilakukan analisis kestabilan di sekitar titik-titik kesetimbangan tersebut. Simulasi numerik untuk kasus endemik memberikan hasil yang sesuai dengan analisis kestabilan.

Kata Kunci: Tuberculosis, model matematika, kasus deteksi, kestabilan, bilangan reproduksi dasar
\end{abstract}

\section{Pendahuluan}

Tuberkulum Bacillus (TB) adalah penyakit menular yang disebabkan oleh bakteri Mycrobacterium tuberculosis. Data WHO menyatakan bahwa TB merupakan penyakit kedua mematikan yang paling fatalistik setelah Human Immunodeficiency Virus (HIV)/Acquired Immunodeficiency Syndrome (AIDS) di negara-negara berkembang. Meskipun dapat diobati dan disembukan, tetapi masih menyebabkan hampir satu setengah juta kematian setiap tahun sesuai data yang tersedia saat ini. Bakteri ini biasanya menyerang paru-paru, tetapi juga dapat menyerang bagian tubuh yang lain seperti ginjal, tulang belakang, dan otak. Menghilangkan penyakit ini tidak mudah karena sulitnya mengembangkan vaksin yang efektif, proses diagnosa yang mahal dna memakan waktu lama, dan pengobatan yang memakan waktu berbulan-bulan.

Dalam paper ini akan dibahas pembentukan dan analisa model matematika terhadap penularan penyakit tuberculosis yang berfokus kepada kasus deteksi dan pengobatan yang dapat digunakan sebagai salah satu cara untuk mengetahui perilaku penyebaran penyakit tuberculosis. Sebagian besar pembahasan pada paper ini merujuk pada tulisan S. Athitan dan M.Gosh [2].

\section{Tinjauan Pustaka}

Sistem persamaan diferensial adalah suatu sistem yang berbentuk

$$
\dot{\mathbf{x}}(t)=\mathbf{f}(\mathbf{x}(t), t), \mathbf{x}\left(t_{0}\right)=\mathbf{x}_{0}, t \in \mathbb{R}
$$


dimana $t$ disebut variabel bebas dan $\mathbf{x}$ disebut variabel tak bebas. Jika $\mathbf{f}$ tidak bergantung kepada variabel bebas $t$ secara eksplisit maka (2.1) disebut sistem persamaan diferensial autonomous. Sehingga (2.1) dapat ditulis menjadi

$$
\dot{\mathbf{x}}(t)=\mathbf{f}(\mathbf{x}(t)), \mathbf{x}\left(t_{0}\right)=\mathbf{x}_{0}, t \in \mathbb{R} .
$$

Definisi 2.1. Titik $\mathbf{x}^{*}$ dikatakan titik kesetimbangan dari (2.2) jika memenuhi $\mathbf{f}\left(\mathbf{x}^{*}\right)=\mathbf{0}$.

Secara umum, kestabilan dari titik kesetimbangan sistem 2.2 dapat dilihat dari solusi sisten persamaan differensialnya, padahal dalam kenyataannya solusi dari sistem 2.2 tidak selalu mudah ditentukan.Untuk mengatasi hal ini, metode pelinieran dapat digunakan untuk menentukan apakah suatu titik kesetimbangan stabil asimtotik atau tidak [4]. Proses pelinieran dilakukan dengan menentukan matriks Jacobian dari sistem (2.1).

Definisi 2.2. [7] Misalkan $f: \mathbb{R}^{n} \rightarrow \mathbb{R}^{n}$ adalah fungsi yang diferensiabel dan kontinu pada himpunan $D \subset \mathbb{R}^{n}$ dan $\mathbf{x}^{*} \in \mathbb{R}^{n}$. Matriks Jacobian dari $f$ disekitar $\mathbf{x}^{*}$, ditulis $J_{f\left(\mathbf{x}^{*}\right)}$, didefinisikan sebagai

$$
J_{f\left(\mathbf{x}^{*}\right)}=\left[\begin{array}{cccc}
\frac{\partial f_{1}\left(\mathbf{x}^{*}\right)}{\partial x_{1}} & \frac{\partial f_{1}\left(\mathbf{x}^{*}\right)}{\partial x_{2}} & \cdots & \frac{f_{1}\left(\mathbf{x}^{*}\right)}{\partial x_{n}} \\
\frac{\partial f_{2}\left(\mathbf{x}^{*}\right)}{\partial x_{1}} & \frac{\partial f_{2}\left(\mathbf{x}^{*}\right)}{\partial x_{2}} & \cdots & \frac{f_{1}\left(\mathbf{x}^{*}\right)}{\partial x_{n}} \\
\vdots & \vdots & \ddots & \vdots \\
\frac{\partial f_{n}\left(\mathbf{x}^{*}\right)}{\partial x_{1}} & \frac{\partial f_{n}\left(\mathbf{x}^{*}\right)}{\partial x_{2}} & \cdots & \frac{f_{n}\left(\mathbf{x}^{*}\right)}{\partial x_{n}}
\end{array}\right]
$$

Sehingga sistem pelinieran yang bersesuaian dengan sistem (2.2) adalah

$$
\dot{\mathbf{y}}=J \mathbf{y}, \quad \mathbf{y} \in \mathbb{R}^{n} .
$$

Karena sistem (2.3) adalah linier, maka solusinya dapat ditulis dalam bentuk

$$
\mathbf{y}=\mathbf{p} e^{\lambda t}
$$

dimana $\lambda$ suatu skalar dan $\mathbf{p}$ suatu vektor konstan tak nol. Dengan mensubtitusikan y ke dalam sistem (2.3), diperoleh

$$
(J-\lambda I) \mathbf{p}=\mathbf{0} .
$$

Dengan demikian $\lambda$ adalah nilai eigen dari matriks $J$ dan $\mathbf{p}$ adalah vektor eigen yang bersesuaian dengan nilai eigen $\lambda$. Karena perilaku solusi $\mathbf{y}=\mathbf{p} e^{\lambda t}$ hanya bergantung kepada nilai eigen $\lambda$, maka kestabilan sistem (2.2) disekitar titik kesetimbangan ditentukan oleh nilai-nilai eigen dari matriks Jacobiannya.

Teorema berikut dapat digunakan untuk mengkaji apakah suatu titik kesetimbangan stabil asimtotik atau tidak stabil.

Teorema 2.3. [3] Misalkan $\mathbf{x}^{*}$ adalah titik kesetimbangan dari persamaan differensial non linier (2.1). $\mathbf{x}^{*}$ adalah

(i) Stabil asimtotik jika bagian riil dari semua nilai eigen matriks Jacobian J adalah negatif.

(ii) Tidak stabil jika ada nilai eigen dari matriks Jacobian yang bagian riilnya adalah positif. 


\section{Konstruksi Model dan Analisis Kestabilan}

\subsection{Model Epidemik SEIR Tuberculosis}

Model SEIR dibagi atas empat kelas individu yang berbeda yaitu populasi susceptible, exposed, infected, dan recovered. Model penyebaran penyakit tuberculosis mengikuti model SEIR, yaitu

$$
\begin{aligned}
& \frac{d S}{d t}=A-d S-\left[\alpha_{1} \eta+\alpha_{2}(1-\eta)\right] I S \\
& \frac{d E}{d t}=(1-p)\left[\alpha_{1} \eta+\alpha_{2}(1-\eta)\right] I S-\beta E I-\left(d+v_{1}+\theta\right) E \\
& \frac{d I}{d t}=p\left[\alpha_{1} \eta+\alpha_{2}(1-\eta)\right] I S+\beta E I-\left(d+d_{1}+v_{2} \eta\right)+\theta E \\
& \frac{d R}{d t}=v_{1} E+v_{2} \eta I-d R
\end{aligned}
$$

dimana parameter yang terlibat dideskripsikan dalam Tabel 1 berikut.

\begin{tabular}{|c|l|}
\hline Parameter & Deskripsi \\
\hline$A$ & Laju munculnya individu baru \\
\hline$d$ & Laju Kematian Alami \\
\hline$\eta$ & Laju pendeteksian kasus \\
\hline$\alpha_{1}$ & Laju penyebaran (Terdeteksi) \\
\hline$\alpha_{2}$ & Laju penyebaran (Tidak Terdeteksi) \\
\hline$p$ & Laju progres infeksi \\
\hline$\beta$ & Laju kontak antara $E$ dan $I$ \\
\hline$\theta$ & Laju perkembangan I dari E \\
\hline$v_{1}$ & Laju kesembuhan tanpa perawatan \\
\hline$v_{2}$ & Laju kesembuhan berdasarkan perawatan \\
\hline$d_{1}$ & Laju kematian berdasarkan infeksi \\
\hline
\end{tabular}

Tabel 1. Deskripsi Parameter Model (3.1)

Model (3.1) dapat disederhanakan menjadi

$$
\begin{aligned}
& \frac{d S}{d t}=A-d S-k_{1} I S \\
& \frac{d E}{d t}=(1-p) k_{1} I S-\beta E I-k_{2} E \\
& \frac{d I}{d t}=p k_{1} I S+\beta E I-k_{3} I+\theta E \\
& \frac{d R}{d t}=v_{1} E+v_{2} \eta I-d R
\end{aligned}
$$

dimana $k_{1}=\left[\alpha_{1} \eta+\alpha_{2}(1-\eta)\right], k_{2}=\left(d+v_{1}+\theta\right)$, dan $k_{3}=\left(d+d_{1}+v_{2} \eta\right)$.

Pada model di atas, semua parameter bernilai positif dan $\alpha_{1}<\alpha_{2}$. Selain itu, daya tahan tubuh diasumsikan berada dalam selang $0<p<1$. 


\subsection{Analisis Kestabilan Model}

Titik kesetimbangan dari model SEIR dapat ditentukan dengan menetapkan sistem persamaan (3.1) sebagai berikut

$$
\frac{d S}{d t}=0, \frac{d E}{d t}=0, \frac{d I}{d t}=0, \text { dan } \frac{d R}{d t}=0 .
$$

Titik kesetimbangan bebas penyakit (disease free equilibrium), diperoleh jika $I=0$, sehingga dari (3.2) diperoleh

$$
A-d S=0
$$

atau

$$
S^{0}=\frac{A}{d} .
$$

Selanjutnya, dari (3.3) diperoleh $E^{0}=0$ dan dari (3.5) diperoleh $R^{0}=0$. Sehingga titik kesetimbangan bebas penyakit :

$$
E_{0}=\left(S^{0}, E^{0}, I^{0}, R^{0}\right)=\left(\frac{A}{d}, 0,0,0\right) .
$$

Dari model (3.1), kompartemen infeksi berada pada kompartemen Exposed dan Infected. Misalkan $\mathbf{F}_{i}$ adalah laju pertumbuhan individu yang baru terinfeksi ke dalam kompartemen ke- $i$ dan $\mathcal{V}_{i}$ adalah laju perpindahan individu pada kompartemen ke- $i$, maka $\mathbf{F}_{i}$ dan $\mathbf{V}_{i}$ dari persamaan (3.2) sampai (3.5) adalah sebagai berikut

$$
\mathbf{F}_{i}=\left[\begin{array}{c}
(1-p) k_{1} I S \\
p k_{1} I S+\beta E I
\end{array}\right] \quad \mathbf{V}_{i}=\left[\begin{array}{c}
\beta E I+k_{2} E \\
k_{3} I-\theta E
\end{array}\right]
$$

Sehingga diperoleh

$$
\begin{aligned}
& F=\left[\begin{array}{ll}
\frac{\partial \mathbf{F}_{1}}{\partial E} & \frac{\partial \mathbf{F}_{1}}{\partial I} \\
\frac{\partial \mathbf{F}_{2}}{\partial E} & \frac{\partial \mathbf{F}_{2}}{\partial I}
\end{array}\right]=\left[\begin{array}{cc}
0 & \left(1-p k_{1}\right) S \\
\beta I & p k_{1} S
\end{array}\right] \\
& V=\left[\begin{array}{ll}
\frac{\partial \mathbf{V}_{1}}{d E} & \frac{\partial \mathbf{V}_{1}}{d I} \\
\frac{\partial \mathbf{V}_{2}}{d E} & \frac{\partial \mathbf{V}_{2}}{d I}
\end{array}\right]=\left[\begin{array}{cc}
\beta I+k_{2} & \beta E \\
-\theta & k_{3}
\end{array}\right] .
\end{aligned}
$$

Dengan mensubtitusi (3.7) ke dalam (3.9) dan (3.10), maka bilangan reproduksi dasar dari model (3.1) adalah

$$
\mathcal{R}_{0}=\rho\left(F V^{-1}\right)=\frac{\left[(1-p) \theta+p k_{2}\right] k_{1} A}{d k_{2} k_{3}} .
$$

Dengan menetapkan $I=I^{*}$, maka diperoleh titik kesetimbangan endemik

$$
\begin{aligned}
E_{1} & =\left(S^{*}, E^{*}, I^{*}, R^{*}\right) \\
& =\left(\frac{A}{d-k_{1} I^{*}}, \frac{(1-p) k_{1} I^{*} S^{*}}{\beta I^{*}+k_{2}}, I^{*}, \frac{v_{1} E^{*}+v_{2} \eta I^{*}}{d}\right) .
\end{aligned}
$$

Subtitusikan $E_{1}$ ke dalam persamaan (3.4), sehingga diperoleh

$$
A_{1}\left(I^{*}\right)^{2}+B_{1} I^{*}+C_{1}=0,
$$


dimana nilai $A_{1}=\beta k_{1} k_{3}, B_{1}=\beta d k_{3}+k_{1} k_{2} k_{3}-\beta k_{1} A$, dan $C_{1}=d k_{2} k_{3}\left(1-\mathcal{R}_{0}\right)$.

Untuk mengetahui banyak titik kesetimbangan endemik, kasus-kasus berikut perlu diperhatikan karena akar-akar (3.13) bergantung kepada tanda dari $A_{1}, B_{1}$, dan $C_{1}$.

Kasus 1 : Misalkan $\beta=0$ maka $A_{1}=0, B_{1}>0$ dan dari (3.13) diperoleh $I^{*}=$ $-\frac{C_{1}}{B_{1}}$. Sehingga terdapat akar positif tunggal jika $C_{1}<0$. Dalam kasus ini, sistem akan memiliki titik kesetimbangan endemik tunggal jika dan hanya jika $C_{1}<0$ ketika $\mathcal{R}_{0}>1$.

Kasus 2 : Jika $B_{1}<0$ dan $C_{1}=0$ atau $B_{1}<0$ dan $B_{1}^{2}-4 A_{1} C_{1}>0$, maka (3.13) mempunyai satu akar positif yang berarti sistem memiliki titik kesetimbangan endemik tunggal.

Kasus 3 : Jika $C_{1}>0, B_{1}<0$ dan $B_{1}^{2}-4 A_{1} C_{1}>0$, maka (3.13) mempunyai dua akar positif yang mengakibatkan sistem mempunyai dua titik kesetimbangan.

\section{Simulasi Numerik}

Simulasi numerik pada paper ini bertujuan untuk melihat penyebaran penyakit tuberculosis. Adapun jumlah populasi awal ditetapkan sebagai berikut:

$$
S(0)=25000, \quad E(0)=2800, \quad I(0)=30, \quad R(0)=20 .
$$

Sedangkan nilai-nilai parameter ditetapkan sebagai berikut. $d=0.0143, \quad A=730$, $\eta=0.7, \quad \alpha_{1}=0.0011, \quad \alpha_{2}=0.0033, \quad p=0.1, \quad \beta=0.5, \quad \theta=0.05, \quad v_{1}=0.2$, $v_{2}=0.5$, dan $d_{1}=0.49$. Sehingga model untuk penyakit Tuberculosis di Indonesia sebagai berikut:

$$
\begin{array}{ll}
\frac{d S}{d t}=73-0.0143 S-0.00176 I S & S(0)=25000 \\
\frac{d E}{d t}=0.00158 I S-0.5 E I-0.2643 E & E(0)=2800 \\
\frac{d I}{d t}=0.000176 I S+0.5 E I-0.8543 I+0.05 E & I(0)=30 \\
\frac{d R}{d t}=0.2 E+0.35 I-0.0143 R & R(0)=20
\end{array}
$$

Dengan menggunakan nilai-nilai parameter tersebut, diperoleh bilangan reproduksi dasar $\mathcal{R}_{0}=28.42$. Karena $B_{1}<0$ dan $B_{1}^{2}-4 A_{1} C_{1}=0.40463>0$ maka persamaan (3.13) mempunyai solusi akar positif dan negatif, karena $I^{*}$ tidak mungkin negatif maka solusi untuk persamaan (3.13) adalah

$$
I^{*}=\frac{-B_{1}+\sqrt{B_{1}^{2}-4 A_{1} C_{1}}}{2 A_{1}}=845.986 .
$$

Sehingga diperoleh titik-titik kesetimbangan sebagai berikut :

$$
\begin{aligned}
& E^{0}=(51048.95,0,0,0) \\
& E_{1}=(485.619,1.537,845.98,20727.464) .
\end{aligned}
$$


Nilai eigen dari matriks Jacobian yang dievaluasi di titik $E^{0}$ adalah

$$
\begin{aligned}
\lambda_{1}=\lambda_{2} & =-0.1430, \\
\lambda_{3} & =-0.721, \\
\lambda_{4} & =8.587 .
\end{aligned}
$$

Karena tidak semua bagian riil dari nilai eigen adalah negatif, maka titik $E^{0}$ adalah tidak stabil asimtotik.

Selanjutnya, nilai eigen dari matriks Jacobian yang dievaluasi di titik $E_{1}$ adalah

$$
\begin{aligned}
\lambda_{1} & =-423.26 \\
\lambda_{2}=\lambda_{3} & =-0.075 \pm 0.8419 i \\
\lambda_{4} & =-0.0143
\end{aligned}
$$

Karena semua bagian riil dai nilai eigen adalah negatif, maka titik $E_{1}$ adalah stabil asimtotik.

Berdasarkan persamaan (4.1) sampai (4.4), kurva solusi untuk masing-masing populasi Susceptible, Exposed, Infected, dan Recovered dari model epidemik Tuberculosis dengan menggunakan model SEIR tampak pada Gambar 1.

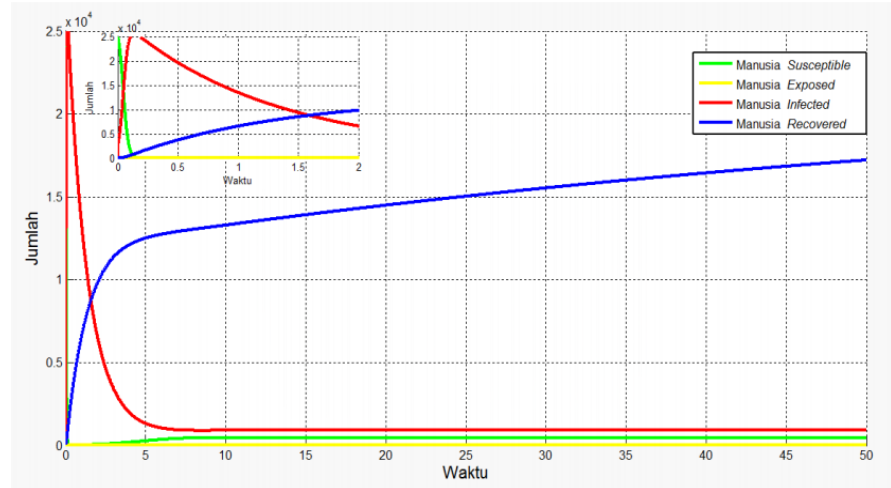

Gambar 1. Kurva Populasi Manusia Susceptible, Exposed, Infected, dan Recovered

\section{Kesimpulan}

Model penyebaran penyakit Tuberculosis dikontruksi berdasarkan empat kelompok populasi, yaitu populasi Susceptibel, Exposed, Infected dan Recovered. Model penularan penyakit Tuberculosis mengikuti model SEIR. Dari hasil analisis kestabilan, diperoleh dua titik kesetimbangan yaitu titik kesetimbangan bebas penyakit $\left(E_{0}\right)$ dan titik kesetimbangan endemik $\left(E_{1}\right)$. Dengan menggunakan nilai-nilai parameter yang dijelaskan pada simulasi numerik, diperoleh bilangan reproduksi dasar $\mathcal{R}_{0}=28.42$. Hal ini menunjukan bahwa kasus penyakit tuberculosis berpotensi menjadi endemik di populasi tersebut. Dari simulasi yang dilakukan dengan menggunakan nilai-nilai parameter tersebut, diperoleh hasil yang sesuai dengan analisis kestabilan, yaitu kurva solusi menuju ke titik kesetimbangan endemik $\left(E_{1}\right)$. 
Untuk penelitian selanjutnya, penulis menyarankan untuk menentukan pengontrol optimal untuk model matematika SEIR penularan penyakit tuberculosis dengan kasus notifikasi.

\section{Daftar Pustaka}

[1] Anton, H and Rorres, C. 1991. Elementary Linear Algebra 10th Edition. Wiley and Sons, New York.

[2] Athithan, S and Gosh, M. 2013. Mathematical modelling of TB with the effects of case detection and treatment. International Journal of Dynamics and Control 1 (3): 223 - 230.

[3] Brannan, J.R and Boyce, W.E. 2011. Differential Equations : An Introduction to Modern Methods and Applications. John Wiley and Sons, New York.

[4] Campbell, S. L and Haberman, R. 2008. Introduction to Differential Equations with Dynamical Systems. Princeton University Press, New Jersey.

[5] Finizio, J and Ladas, T. 1982. An Introduction to Differential Equations. Wadsworth Publishing Company Belmon, California.

[6] Info DATIN. 2015. Tuberculosis : Temukan, Obati Sampai Sembuh. Kementrian Kesehatan RI, Jakarta.

[7] Kelley, W. G and Peterson, A.C. 2010.The Theory of Differential Equations. Springer-Verlag, New York

[8] Kementerian Kesehatan Republik Indonesia. 2015. Profil Kesehatan Indonesia 2014. Jakarta.

[9] Oktafiani, L.D. 2013. Penentuan Bilangan Reproduksi Dasar dengan Menggunakan Matriks Next-Generation Pada model West Nile Virus. Institut Pertanian Bogor, Bogor.

[10] Diekmann, O and Heesterbeek, J.A.P. 1999. Mathematical Epidemiology of Infectious Diseases: Model Building, Analyis and Interpretation. Wiley, New York.

[11] Okuonghae, D and Aihie, V. 2008. Case detection and direct observation therapy strategy (DOTS) in Nigeria: its effect on TB dynamics. J. Biol. Syst. 16: $1-31$.

[12] Putri, D. D. 2015. Pemodelan Penyebaran Penyakit Flu Burung. Universitas Andalas, Padang.

[13] Van den Driessche, P and Freud, B. 2008. Mathematical Epidemiology. Spinger-Verlag, Berlin.

[14] Van den Driessche, P and Watmough, J. 2002. Reproduction numbers and subthreshold endemic equilibria for comparmental model of transmission. Math Biosci. 180: 29 - 48.

[15] Wulandari, U. N. 2013. Analisis Model Epidemik MSEIR Pada Penyebaran Penyakit Difteri. Jawa Timur, Indonesia: Digital Repository Universitas Jember.

[16] World Health Organization. 2015. Global Tuberculosis Control. Home Page http://www.who.int/tb/publications/global-report. 